\title{
Communication \\ Promises and Challenges of Microalgal Antioxidant Production
}

\author{
Clementina Sansone * and Christophe Brunet \\ Stazione Zoologica Anton Dohrn, Istituto Nazionale di Biologia, Ecologia e Biotecnologie marine, Villa \\ Comunale, 80121 Napoli, Italy \\ * Correspondence: clementina.sansone@szn.it; Tel.: +39-0815833262
}

Received: 3 June 2019; Accepted: 25 June 2019; Published: 27 June 2019

\begin{abstract}
The exploration of natural antioxidants for nutraceuticals and pharmaceuticals industries has recently increased. This communication aims to grasp the relevance of microalgae in the panorama of natural antioxidant molecules supply to industrial applications as alternatives and/or complements to those typically used from higher plants. Microalgal richness in antioxidant compounds and scavenging ability compared to higher plants is discussed in the context of microalgal biodiversity. We mainly focus on families of powerful antioxidant compounds that have been scarcely investigated in microalgae, such as phenolic compounds, sterols, or vitamins, discussing the promise and challenges of microalgae as providers of health benefits, for instance, through their use as functional food ingredients.
\end{abstract}

Keywords: microalgae; antioxidant; biodiversity

\section{Antioxidants and the Ability of Organisms to Finely Balance Oxygen between Cell Life and Death}

Oxygen is essential but can be harmful for life on Earth, causing oxidative stress in cells and tissues through the development of ROS (reactive oxygen species) [1]. Lipids, nucleic acids (RNA and DNA), and proteins represent the main targets of ROS, reactive nitrogen species (RNS), and reactive sulfur species (RSS) [2].

Antioxidants, scavengers of ROS, are substances able to protect, scavenge, and repair oxidative damage, thereby protecting target structures or molecules from oxidative injuries [3]. In protecting against ROS, antioxidants help optimize human physiological functions, thus helping to maintain a healthy state and protect against diseases. Numerous compounds, such as some vitamins, carotenoids, and polyphenols (such as flavonoids), play a relevant role in preventing oxidative damages caused by free radicals by scavenging activity, and/or have a key role in the prevention of degenerative neuropathies or diabetes or in preventing cardiovascular diseases or cancers, as well as exerting anti-inflammatory, anti-viral, or anti-ageing activities [4-9].

The antioxidant endogenous machinery in humans, although highly efficient, is not enough by itself to counteract the development or harmful effects of ROS, thus requiring a supplement of exogenous antioxidant molecules. Indeed, recent studies report that human longevity is also related to the ingestion of food with high content of antioxidants, which help in protecting the body against ROS [10]. Exogenous antioxidants are mainly derived from photosynthetic organisms and belong to different families such as polyphenols (phenolic acids, flavonoids, anthocyanins, lignans, and stilbenes), carotenoids (xanthophylls and carotenes), sterols, or vitamins (vitamins B, D, E, and C) [11]. Some of them are only synthesized in vegetables and bio-accumulate in animals [10] and along ecosystem trophic web, such as in marine systems [12]. The sea is a rich source of antioxidants, such as vitamins $B_{12}, C, D, E$, peptides, amino acids, chitooligosaccharide derivatives, astaxanthin and 
generally carotenoids, sulphated polysaccharides, sterols, phlorotannins, phenolic compounds, and flavones [13-18].

Investigating new natural antioxidants for nutraceuticals and pharmaceuticals industries is a relevant key-research topic [19]; microalgae are highly promising in this context [11-20].

\section{The Small Size of the Bioactive Power: Promises of Microalgae as Antioxidant Providers}

Microalgae are characterized by a high biodiversity (Table 1) and richness in terms of adaptive traits allowing them to colonize all kind of aquatic ecosystems.

Table 1. Principal marine microalgal classes (ca. 50,000 known species, estimated to be $200,000-800,000$ species [21]; microalgal biomass represents ca. one-quarter of the total vegetation biomass in the world) and their potential in antioxidant biotechnology.

\begin{tabular}{|c|c|c|c|c|c|c|}
\hline Classes & $\begin{array}{c}\text { Species } \\
\text { Number } \\
\text { Estimation }\end{array}$ & Distribution & Forms & $\begin{array}{c}\text { Known Interests } \\
\text { for Bioactive } \\
\text { Families }\end{array}$ & Applications & Expectations \\
\hline Bacillariophyceae & $10,000[22]$ & ubiquitous & $\begin{array}{l}\text { single, filament } \\
\text { colonial }\end{array}$ & carotenoids & little & $\begin{array}{l}\text { polyphenols, } \\
\text { vitamins [23]; } \\
\text { sterols [16] }\end{array}$ \\
\hline Chlorophyceae & 8000 [21] & ubiquitous & flagellate single & PUFAs, carotenoids & yes & \\
\hline Cyanophyceae & $2000[24,25]$ & $\begin{array}{l}\text { oligotrophic, } \\
\text { coastal }\end{array}$ & $\begin{array}{c}\text { filament, } \\
\text { colonial single }\end{array}$ & $\begin{array}{l}\text { phycobiliproteins } \\
\text { proteins carotenoids }\end{array}$ & yes & $\begin{array}{c}\text { vitamin B12 [26] } \\
\text { vitamin E [27] }\end{array}$ \\
\hline Dinophyceae & $1500[28]$ & ubiquitous & flagellate & sterols [16] & little & MAAs [29] \\
\hline $\begin{array}{l}\text { Prymnesiophyceae } \\
\text { Pavlovophyceae }\end{array}$ & $500[21]$ & ubiquitous & $\begin{array}{l}\text { single, filament } \\
\text { flagellate }\end{array}$ & DMSP & little & $\begin{array}{c}\text { DMSP [30] } \\
\text { carotenoids } \\
\text { sterols }[16,31]\end{array}$ \\
\hline Crysophyceae & $400[21]$ & $\begin{array}{l}\text { mostly } \\
\text { ubiquitous }\end{array}$ & $\begin{array}{c}\text { filament, } \\
\text { colonial single }\end{array}$ & - & no & \\
\hline Cryptophyceae & $200[32]$ & ubiquitous & Often flagellate & phycobiliproteins & little & \\
\hline Prasinophyceae & $100[21]$ & $\begin{array}{l}\text { mostly } \\
\text { ubiquitous }\end{array}$ & flagellate & - & no & \\
\hline Pelagophyceae & $10[21]$ & $\begin{array}{l}\text { oligotrophic, } \\
\text { coastal }\end{array}$ & single & - & no & \\
\hline Bolidophyceae & $15[21]$ & oligotrophic & single & - & no & \\
\hline
\end{tabular}

PUFAs = polyunsaturated fatty acids; MAAs = mycosporine-like amino acids; DMSP = dimethylsulph oniopropionate.

The metabolic diversity of microalgae, stemming from the adaptive flexibility of the microalgal world, makes them promising candidates to be exploited in biotechnological applications [33]. The advantages of microalgae compared to higher plants or fruits-the actual main source of antioxidants for human-derive from the combination of being photosynthetic, mainly unicellular, displaying high growth rate, and occupying reduced space for their large cultivation.

In Table 2, we report data from literature comparing the antioxidant activity of microalgae vs. higher plants or fruits. 
Table 2. Antioxidant activity (Trolox equivalents, $\left.\mu \mathrm{mol}\left(\mathrm{g}^{-1} \mathrm{DM}\right)\right)$ of different higher plants and microalgal classes.

\begin{tabular}{ccc}
\hline Species & Trolox Equivalents $\boldsymbol{\mu}$ mol $\left.\mathbf{~ g}^{-\mathbf{1}} \mathbf{D M}\right)$ & References \\
\hline Rubus sp. & $\sim 224.80$ & {$[34]$} \\
Rosmarinus sp. & $\sim 116.00$ & {$[35,36]$} \\
Zataria multiflora Boiss & $\sim 108.00$ & {$[35,37]$} \\
Perlagonium graveolens L'Hér. & $\sim 36.00$ & {$[35,38]$} \\
Chamaemelum nobile L. & $\sim 7.60$ & {$[35,39]$} \\
Achillea wilhelmsii C. Koch & $\sim 3.00$ & {$[35,40]$} \\
Carthamus tinctorius L. & $\sim 1.80$ & {$[35,41]$} \\
Eustigmatophyceae & $46.16-258.20$ & {$[42,43]$} \\
Chlorophyceae & $5.50-214.34$ & {$[42-44]$} \\
Xanthophyceae & $\sim 122.52$ & {$[42,43]$} \\
Cryptophyceae & $30.44-110.42$ & {$[42,43]$} \\
Pavlophyceae & $24.19-94.19$ & {$[43,45]$} \\
Euglenoidea & $\sim 86.99$ & {$[42,43]$} \\
Chrysophyceae & $16.61-67.95$ & {$[42,43]$} \\
Bacillariophyceae & $\sim 57.35$ & {$[42,43]$} \\
Cyanophyceae & $4.55-48.90$ & {$[42-46]$} \\
Dinophyceae & $2.40-38.90$ & {$[42-47]$} \\
\hline
\end{tabular}

The antioxidant power of microalgae is comparable, and even higher than, the antioxidative activity of higher plants or fruits (Table 2). In both cases, the variability is high (ranging from $\approx 4$ to 260 Trolox equivalents $\left.\mu \mathrm{mol} \mathrm{g}{ }^{-1} \mathrm{DM}\right)$. Interestingly, the antioxidant potential of some classes of microalgae such as Chlorophyta and Eustigmatophyceae (Table 2, highest values ranged from 214 to 258 Trolox equivalents $\mu \mathrm{mol} \mathrm{g}{ }^{-1} \mathrm{DM}$ ) is comparable to the antioxidant activity displayed by Rubus sp. (raspberry) fruits (224 Trolox equivalents $\mu \mathrm{mol} \mathrm{g}^{-1} \mathrm{DM}$ [34]). These results point to the reason that there is such great interest in the highly promising microalgae as antioxidant providers for nutraceuticals and human wellness, and invoke the necessity of further exploring this great potential. The relevant antioxidant activity is probably related to the high content and diversity of antioxidant molecules in microalgae, which are a source of a wide range of antioxidant molecules [42-48] (Figure 1), some of which are aquatic-specific, while others are shared with terrestrial plants.

Astaxanthin, an "aquatic" carotenoid, is one of the most known for its health properties [49]. Among carotenoids, many are shared with higher plants [50], while algae (micro- and macro-) contain peculiar ones, such as fucoxanthin, which is well known for its bioactivity [51], and many others, such as diatoxanthin, diadinoxanthin, siphonein, or siphonaxanthin, with potentially interesting bioactivity [21,52]. Also, aquatic protein pigments such as phycobiliproteins are of great interest for their antioxidant and pharmaceutical activity [53]. Aquatic organisms, like microalgae, can also be providers of other sources of antioxidant molecules, such as the mycosporine-like amino acids (MAAs, [29]), which act as sunscreens against UVs and also possess antioxidant and osmoprotectant activities [54]. Moreover, the osmolyte dimethylsulphoniopropionate (DMSP) and its enzymatic cleavage product dimethylsulphide (DMS), produced in some microalgae have also been shown to display antioxidant activity [30].

Other families with powerful antioxidant activity that are well known in higher plants are also present in microalgae, although they tend to be far less studied in microalgae than in terrestrial plants (e.g., phenolic compounds, sterols and vitamins). Phenolic compounds, including several classes of flavonoids, such as isoflavones, flavanones, flavonols, and dihydrochalcones, have a protective effect on the liver, which is one of the principal targets of ROS-related diseases [55]. Spirulina sp., aquatic cyanobacteria, are a rich source of phenolic compounds including gallates, chlorogenates, cinnamates, pinostrobates, and p-hydroxybenzoates [56] as well as salicylic, trans-cinnamic, synapic, chlorogenic, and caffeic acids [57]. Previous studies have looked at the content and diversity of sterols in microalgae 
(see [16] and references therein) and have reported that microalgae can be relevant producers of sterols. Microalgal sterols have beneficial health effects in diseases such as hypocholesterolemia and neurological diseases like Parkinson illness, and also possess anticancer and anti-inflammatory activities [17].

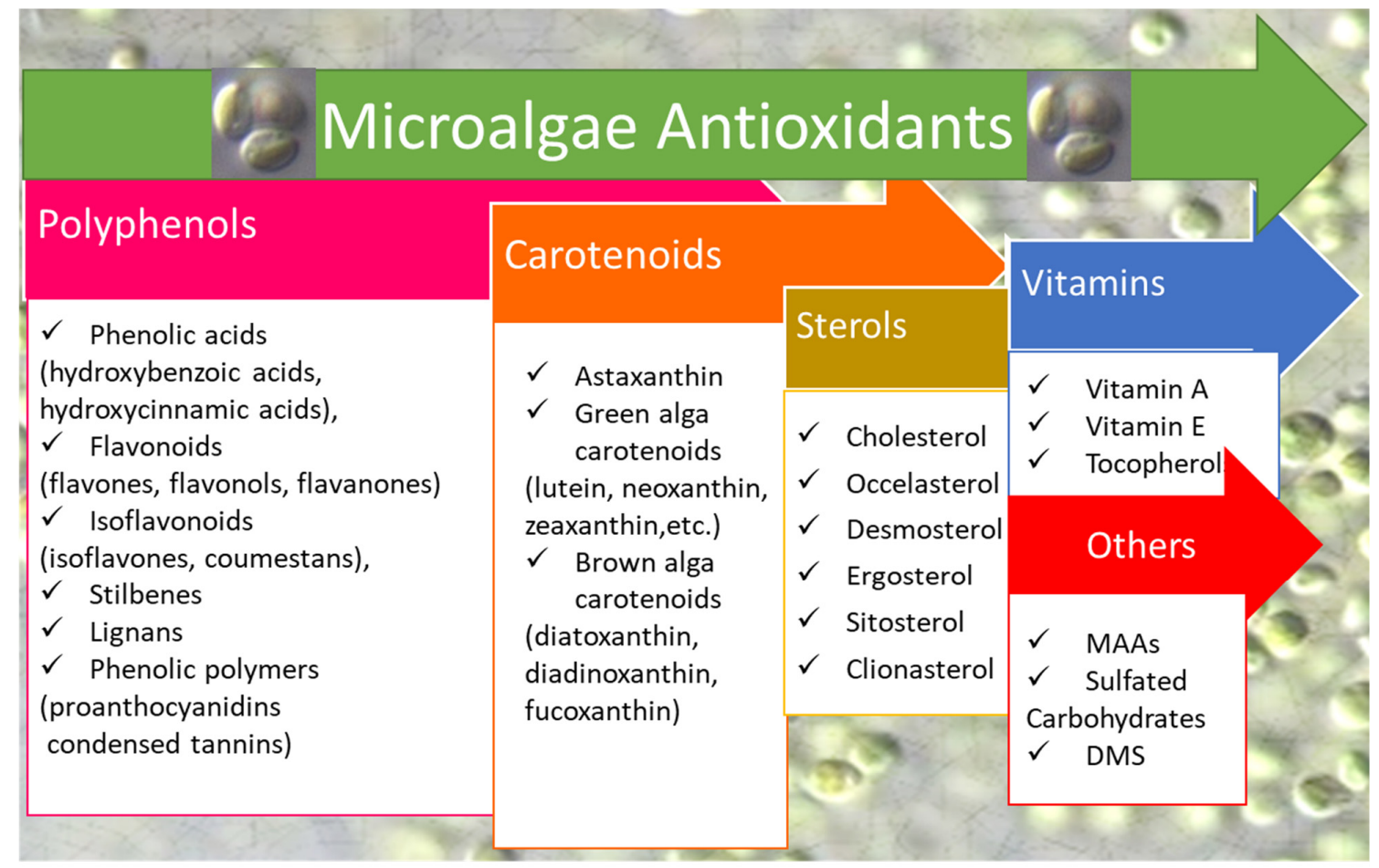

Figure 1. Challenging microalgal antioxidants of interest for biotechnological issues. DMS: dimethylsulphide.

Together with phenols and sterols, microalgae are also a rich source of vitamins, such as vitamin $\mathrm{E}$ (tocopherols), D, and C, as well as $\beta$-carotene (pro-vitamin A), pyridoxine, nicotinamide (vitamin $B_{3}$ ), thiamine (vitamin $B_{1}$ ), riboflavin, and biotin [58]. Sulfated polysaccharides isolated from microalgae also display relevant antioxidant properties with effective scavenging abilities on superoxide radicals, hydroxyl radicals, and hydroxyl peroxide [59]. Furthermore, microalgae are also a rich source of protein enzymes, peptides, and amino acids [60], which are necessary for the normal physiological activities of cells and tissues and have strong health-protecting effects [60].

\section{BioDivAct (Biodiversity and Bioactivity): A Microalgal Antioxidant Challenging Project}

Activation of physiological regulation pathways induced by environmental stress generates the synthesis of molecules that are able to react against ROS. These bioactive molecules are of strong interest for biotechnological applications, especially for nutraceuticals and cosmetics. Investigating natural sources of bioactive molecules and enhancing their synthetic yield are biotechnological requirements for further addressing societal needs in terms of human wellness. Marine microalgae, which represent a reservoir of known and unknown biodiversity, can majorly contribute to this goal [61]. Indeed, microalgal diversity (Table 1) offers a broad range of adaptive biological features (which may be fruitful for biotechnological applications [48]) related to their growth in the most varied marine systems, from intertidal sediments, polar or ultra-oligotrophic systems, to coastal ecosystems. Yet, a lack of information on regulative processes and their variability among biodiversity is notable, except on what is regarding the photoprotective responses such as the xanthophyll cycle and NPQ activation [62].

The challenge is to investigate the diversity of bioactive molecules and its modulation along the microalgal biodiversity scale. 
The steps to reach the "microalgal antioxidant illuminated life" are defined below:

1) Deeply investigate the content and diversity of the least known families of microalgal bioactive molecules. Phenolics, flavonoids, and vitamins (A, B, C, D, and E) have been scarcely documented in microalgae [16-20,23,63-77]. Compared to these families, microalgal sterols have been more documented thanks to the pioneering works of Volkman [16,63]. These groups of biotechnologically appealing bioactive molecules require deep investigations in microalgae. Also, other promising bioactive molecules such as the mycosporine-like amino acids [29,78] have to be further investigated.

2) Deploy a large screening of the little-known antioxidant molecules/families among the microalgal biodiversity, as recently conducted by Volkman on microalgal sterols [16]. One of the aims of this action is to generate a crossed biodiversity (BioDivAct) matrix providing information on the relationship between taxa/groups and the concentrations and relative contributions of the diverse families. From this, the "key molecule concept" can be proposed for the different microalgal groups (i.e., with "key" defined as molecules present in high quantity in cells, or by their high and/or peculiar bioactivity interest.).

3) Understand the role of these key molecules and their place in cells (e.g., chloroplasts, mitochondria, etc.).

4) Decipher the main biosynthetic pathways of these molecules.

5) Assess and compare the antioxidant activities of single molecules or families harvested from the microalgal diversity. These data must thus be included in the BioDivAct matrix. It is expected that some single molecules or subfamilies of molecules display greater activity of scavenging and/or repairing than others, as it is generally found in higher plants/fruits.

6) Investigate the regulative properties driving the synthesis of bioactive molecules in the different microalgal groups in relation to the functional groups they belong. This approach was already carried out by Dimier et al. [79] on the xanthophyll cycling pigments modulation with respect to the ecosystem properties where the microalgae come from. This can be done on cells grown under different environmental conditions, mainly by manipulating light (intensity, daily light dose, spectral composition [16,23,78]), or through others forms of manipulations [16], such as temperature, salinity, nutrient concentrations, and water movement during cultivation. Spectral light modulation, mainly varying the red:blue ratio, is of great interest for manipulating microalgal physiology and regulative properties [23].

7) Assess the antioxidative power of mixes of molecules/families harvested from mono-microalgal cultures. This feature is relevant since one way to enhance bioactivity concerns the synergism between different molecules/groups extracted together [80].

8) Optimize protocols to maximize the harvested yield of the targeted compounds and investigate procedures to maximize the extraction efficiency of bioactive mixtures from microalgae.

9) Investigate the biological and environmental conditions for developing the co-cultivation of different microalgal groups in order to provide an efficient complementary of the bioactive molecules.

The microalgal antioxidant challenge, with the specific aims described previously, will enhance the added value of microalgal harvested biomass in terms of bioactivity and thus its role in nutraceutics and/or cosmetics. Indeed, this will help to lower the cost of the production rate for obtaining a high-quality biomass. The costs of microalgal growth for cosmetics or nutraceutical applications (i.e. using them for bioactive compounds) have not yet been estimated. Attempts on comparing the costs of microalgal production vs. terrestrial plants production have been carried out [81], especially for energetics application, such as lipid production. The results of the previous study suggested that the production of algal biomass can be profitable, compared to higher plants, but requires a maximization of yields, and an optimization of harvesting and processing strategies for microalgal cultivation and 
for the enhancement of biomass quality (e.g., antioxidant richness for cosmetics or nutraceutical applications).

Author Contributions: C.S. and C.B. equally contributed to this study, and both authors were responsible for preparing, writing, and reviewing the manuscript.

Funding: This research received no external funding.

Acknowledgments: The authors acknowledge the three reviewers for their comments and criticisms on a previous version of the manuscript.

Conflicts of Interest: The authors declare no conflict of interest.

\section{References}

1. Lane, N. Elixir of Life and Death. In Oxygen: The Molecule That Made the World, 2nd ed.; Oxford Landmark Science: New York, NY, USA, 2002; p. 384.

2. Hultqvust, M.; Olsson, L.A.; Gelderman, K.A.; Holmdah, R. The protective role of ROS in autoimmune disease. Trends Immunol. 2009, 30, 201-208. [CrossRef] [PubMed]

3. Halliwell, B. Biochemistry of oxidative stress. Biochem. Soc. Trans. 2007, 35, 1147-1150. [CrossRef] [PubMed]

4. Scalbert, A.; Manach, C.; Morden, C.; Remesy, C.; Jimenez, L. Dietary polyphenols and prevention of diseases. Crit. Rev. Food Sci. Nutri. 2005, 45, 287-306. [CrossRef] [PubMed]

5. Galasso, C.; Corinaldesi, C.; Sansone, C. Carotenoids from marine organisms: Biological functions and industrial applications. Antioxidants 2017, 6, 96. [CrossRef] [PubMed]

6. Holick, C.N.; Michaud, D.S.; Stolzenberg Solomon, R.; Mayne, S.T.; Pietinen, P.; Taylor, P.R.; Albanes, D. Dietary carotenoids, serum beta-carotene, and retinol and risk of lung cancer in the alpha-tocopherol, beta-carotene cohort study. Am. J. Epidemiol. 2002, 156, 536-547. [CrossRef]

7. Gomes, F.S.; Costa, P.A.; Campos, M.B.D.; Tonon, R.V.; Couri, S.; Cabral, L.M.C. Watermelon juice pre-treatment with microfiltration process for obtaining lycopene. Int. J. Food Sci. Technol. 2013, 48, 601-608. [CrossRef]

8. Gupta, V.K.M.; Shrivastava, R.K.; Singh, N. Status of exogenous antioxidant, total antioxidant capacity and oxidative stress in SCA patients. Indian J. Appl. Res. 2018, 8, 112-118.

9. Wang, T.Y.; Li, Q.; Bi, K.S. Bioactive flavonoids in medicinal plants: Structure, activity and biological fate. Asian J. Pharma Sci. 2018, 13, 12-23. [CrossRef]

10. Wilson, D.; Nash, P.; Buttar, H.; Griffiths, K.; Singh, R.; De Meester, F.; Takahashi, T. The role of food antioxidants, benefits of functional foods, and influence of feeding habits on the health of the older person: An overview. Antioxidants 2017, 6, 81. [CrossRef]

11. Xu, D.P.; Li, Y.; Meng, X.; Zhou, T.; Zhou, Y.; Zheng, J.; Li, H.B. Natural Antioxidants in Foods and Medicinal Plants: Extraction, Assessment and Resources. Int. J. Mol. Sci. 2017, 18, 96. [CrossRef]

12. Snoeijs, P.; Sylvander, P.; Häubner, N. Aquatic Primary producers as a Driving Force for Ecosystem Responses to Large-Scale Environmental Changes. In Oxidative Stress in Aquatic Ecosystems; Abele, D., Vázquez-Medina, J.P., Zenteno-Savín, T., Eds.; Wiley-Blackwell: Oxford, UK, 2011; pp. 72-88.

13. Newman, D.J.; Cragg, G.M. Marine natural products and related compounds in clinical and advanced preclinical trials. J. Nat. Prod. 2004, 67, 1216-1238. [CrossRef] [PubMed]

14. Aklakur, M. Natural antioxidants from sea: A potential industrial perspective in aquafeed formulation. Rev. Aquacult. 2018, 10, 385-399. [CrossRef]

15. Al-Saif, S.S.; Abdel-Raouf, N.; El-Wazanani, H.A.; Aref, I.A. Antibacterial substances from marine algae isolated from Jeddah coast of Red sea, Saudi Arabia. Saudi J. Biol. Sci. 2014, 21, 57-64. [CrossRef] [PubMed]

16. Volkman, J.K. Sterols in microalgae. In The Physiology of Microalgae; Borowitzka, M.A., Beardall, J., Raven, J.A., Eds.; Developments in Applied, Phycology; Springer International Publishing: Dordrecht, the Netherlands, 2016; pp. 485-505.

17. Galasso, C.; Gentile, A.; Orefice, I.; Ianora, A.; Bruno, A.; Noonan, D.M.; Sansone, C.; Albini, A.; Brunet, C. Microalgal derivatives as potential nutraceutical and food supplements for human health: A focus on cancer prevention and interception. Nutrients 2019, 11, 1226. [CrossRef] [PubMed] 
18. Ali, H.E.A.; Shanab, S.M.M.; Shalaby, E.A.A.; Eldmerdash, U.; Abdullah, M.A. Screening of microalgae for antioxidant activities, carotenoids and phenolic contents. In Applied Mechanics and Materials; Trans Tech Publications: Stafa-Zurich, Switzerland, 2014; Volume 625, pp. 156-159.

19. Asif, M. Chemistry and antioxidant activity of plants containing some phenolic compounds. Chem. Int. 2015, 1, 35-52.

20. Natrah FM, I.; Yusoff, F.M.; Shariff, M.; Abas, F.; Mariana, N. Screening of Malaysian indigenous microalgae for antioxidant properties and nutritional value. J. Appl. Phycol. 2007, 19, 711. [CrossRef]

21. Guiry, M.D. How many species of algae are there? J. Phycol. 2005, 48, 1057-1063. [CrossRef] [PubMed]

22. Norton, T.A.; Melkonian, M.; Andersen, R.A. Algal biodiversity. Phycologia 1996, 35, 308-326. [CrossRef]

23. Smerilli, A.; Orefice, I.; Corato, F.; Ruban, A.; Brunet, C. Photoprotective and antioxidant responses to light spectrum and intensity variations on a coastal diatom. Environ. Microbiol. 2017, 19, 611-627. [CrossRef]

24. Mur, L.R.; Skulberg, O.M.; Utkilen, H. Cyanobacteria in the environment. In Toxic Cyanobacteria in Water: A GUIDE to their Public Health Consequences, Monitoring and Management; Ingrid Chorus and Jamie Bartram: London, UK, 1999; pp. 25-54.

25. Walter, J.M.; Coutinho, F.H.; Dutilh, B.E.; Swings, J.; Thompson, F.L.; Thompson, C.C. Ecogenomics and Taxonomy of Cyanobacteria Phylum. Front. Microbiol. 2017, 8, 2132. [CrossRef]

26. Abed, R.M.M.; Dobretsov, S.; Sudesh, K. Applications of cyanobacteria in biotechnology. J. Appl. Microbiol. 2009, 106, 1-12. [CrossRef] [PubMed]

27. de Morais, M.G.; da Silva, V.B.; de Morais, E.G.; Vieira Costa, J.A. Biologically active metabolites synthesized by microalgae. BioMed Res. Int. 2015, 2015, 835761. [CrossRef]

28. Gómez, F. A list of free-living dinoflagellate species in the world's oceans. Acta Bot. Croat. 2005, 64, 129-212.

29. Llewellyn, C.A.; Airs, R.L. Distribution and abundance of MAAs in 33 species of microalgae across 13 classes. Mar. Drugs 2010, 8, 1273-1291. [CrossRef] [PubMed]

30. Sunda, W.; Kieber, D.J.; Kiene, R.P.; Huntsman, S. An antioxidant function for DMSP and DMS in marine algae. Nature 2002, 418, 317-320. [CrossRef]

31. Santhosh, S.; Dhandapani, R.; Hemalatha, N. Bioactive compounds from Microalgae and its different applications-A review. Adv. Appl. Sci. Res. 2016, 7, 153-158.

32. Metfies, K.; Gescher, C.; Frickenhaus, S.; Wichels, R.N.A.; Gerdts, G.; Knefelkamp, B.; Wiltshire, K.; Medlin, L. Contribution of the class cryptophyceae to phytoplankton structure in the German bight. J. Phycol. 2010, 46, 1152-1160. [CrossRef]

33. Yusoff, F.M.; Nagao, N.; Imaizumi, Y.; Toda, T. Bioreactor for Microalgal Cultivation Systems: Strategy and Development. In Prospects of Renewable Bioprocessing in Future Energy Systems. Biofuel and Biorefinery Technologies; Rastegari, A., Yadav, A., Gupta, A., Eds.; Springer: Cham, Switzerland, 2019; p. 10.

34. Chen, L.; Xin, X.L.; Zhang, H.C.; Yuan, Q.P. Phytochemical properties and antioxidant capacities of commercial raspberry varieties. J. Funct. Foods. 2013, 5, 508-515. [CrossRef]

35. Goodarzi, V.; Zamani, H.; Bajuli, L.; Moradshahi, A. Evaluation of antioxidant potential and reduction capacity of some plant extracts in silver nanoparticles' synthesis. Mol. Biol. Res. Commun. 2014, 3, 165-174.

36. Zappalà, A.; Vicario, N.; Calabrese, G.; Turnaturi, R.; Pasquinucci, L.; Montenegro, L.; Spadaro, A.; Parenti, R.; Parenti, C. Neuroprotective effects of Rosmarinus officinalis L. extract in oxygen glucose deprivation (OGD)-Injured human neural-like cells. Nat. Prod. Res 2019, 1-7. [CrossRef]

37. Mojaddar Langroodi, A.; Tajik, H.; Mehdizadeh, T. Antibacterial and antioxidant characteristics of Zataria multiflora Boiss essential oil and hydroalcoholic extract of Rhus coriaria L. J. Food Qual. Hazards Control 2019, 6, $16-24$.

38. Lohani, A.; Mishra, A.K.; Verma, A. Cosmeceutical potential of geranium and calendula essential oil: Determination of antioxidant activity and in vitro sun protection factor. J. Cosmet Dermatol. 2019, 18, 550-557. [CrossRef] [PubMed]

39. Heghes, S.C.; Vostinaru, O.; Rus, L.M.; Mogosan, C.; Iuga, C.A.; Filip, L. Antispasmodic effect of essential oils and their constituents: A review. Molecules 2019, 24, 1675. [CrossRef] [PubMed]

40. Amiri, M.; Navabi, J.; Shokoohinia, Y.; Heydarpour, F.; Bahrami, G.; Behbood, L.; Derakhshandeh, P.; Momtaz, S.; Farzaei, M.H. Efficacy and safety of a standardized extract from Achillea wilhelmsii C. Koch in patients with ulcerative colitis: A randomized double blind placebo-controlled clinical trial. Complement. Ther. Med 2019, in press. [CrossRef] 
41. Sharifi, P.; Shorafa, M.; Mohammadi, M.H. Comparison of the effect of Cow manure, Vermicompost, and Azolla on safflower growth in a saline-sodic soil. Commun. Soil Sci. Plant Anal. 2019. [CrossRef]

42. Assunção, M.F.G.; Amaral, R.; Martins, C.B.; Ferreira, J.D.; Ressurreição, S.; Santos, S.D.; Varejão, J.M.T.B.; Santos, L.M.A. Screening microalgae as potential sources of antioxidants. J. Appl. Phycol. 2017, 29, 865-877. [CrossRef]

43. Banskota, A.H.; Sperker, S.; Stefanova, R.; McGinn, P.J.; O’Leary, S.J.B. Antioxidant properties and lipid composition of selected microalgae. J. Appl. Phycol. 2019, 31, 309-318. [CrossRef]

44. Li, H.; Cheng, K.; Wong, C.; Fan, K.; Chen, F.; Jiang, Y. Evaluation of antioxidant capacity and total phenolic content of different fractions of selected microalgae. Food Chem. 2007, 102, 771-776. [CrossRef]

45. Schieler, B.M.; Soni, M.V.; Brown, C.M.; Coolen, M.J.L.; Fredricks, H.; Van Mooy, B.A.S.; Hirsh, D.J.; Bidle, K.D. Nitric oxide production and antioxidant function during viral infection of the coccolithophore Emiliania huxleyi. ISME J. 2019, 13, 1019-1031. [CrossRef]

46. Fimbres-Olivarria, D.; Carvajal-Millan, E.; Lopez-Elias, J.A.; Martinez-Robinson, K.G.; Miranda-Baeza, A.; Martinez-Cordova, L.R.; Valdez-Holguin, J.E. Chemical characterization and antioxidant activity of sulfated polysaccharides from Navicula sp. Food Hydrocoll. 2018, 75, 229-236. [CrossRef]

47. Delfan, P.; Mortazavi, A.; Rad, A.H.E.; Zenoozian, M.S. Measurement of phenolic content and antioxidant capacity of Pennyroyal (Mentha pulegium L.) and microalgae Spirulina platensis extracted by steeping, ultrasonic and microwave methods. J. Food Process. Technol 2019, 9, 712.

48. Khan, M.I.; Shin, J.H.; Kim, J.D. The promising future of microalgae: Current status, challenges, and optimization of a sustainable and renewable industry for biofuels, feed, and other products. Microb. Cell Fact. 2018, 17, 36. [CrossRef] [PubMed]

49. Zhang, D.; Wan, M.; del Rio-Chanona, E.A.; Huang, J.; Wang, W.; Li, Y.; Vassiliadis, V.S. Dynamic modelling of Haematococcus pluvialis photoinduction for astaxanthin production in both attached and suspended photobioreactors. Algal Res. 2016, 13, 69-78. [CrossRef]

50. Barredo, J.L. Microbial Carotenoids from Bacteria and Microalgae. In Methods and Protocols; Humana Press: New York, NY, USA, 2012.

51. Xia, S.; Wang, K.; Wan, L.; Li, A.; Hu, Q.; Zhang, C. Production, Characterization, and Antioxidant Activity of Fucoxanthin from the Marine Diatom Odontella aurita. Mar. Drugs 2013, 11, 2667-2681. [CrossRef] [PubMed]

52. Takaichi, S. Carotenoids in algae: Distributions, biosynthesis and functions. Mar. Drugs 2011, 9, 1101-1118. [CrossRef] [PubMed]

53. Manirafasha, E.; Ndikubwimana, T.; Zeng, X.; Lu, Y.; Jing, K. Phycobiliprotein: Potential microalgae derived pharmaceutical and biological reagent. Biochem. Eng. J. 2016, 109, 282-296. [CrossRef]

54. Künzel, A. Aharon Oren: Halophilic microorganisms and their environments. Int. Microbiol. 2003, 6, 151-152. [CrossRef]

55. Sánchez-Salgado, J.C.; Estrada-Soto, S.; García-Jiménez, S.; Montes, S.; Gómez-Zamudio, J.; Villalobos-Molina, R. Analysis of flavonoids bioactivity for cholestatic liver disease: Systematic literature search and experimental approaches. Biomolecules 2019, 9, 102.

56. Klejdus, B.; Kopeckýb, J.; Benešová, L.; Vaceka, J. Solid-phase/supercritical-fluid extraction for liquid chromatography of phenolic compounds in freshwater microalgae and selected cyanobacterial species. J. Chromatogr. 2009, 1216, 763-771. [CrossRef]

57. Miranda, M.S.; Cintra, R.G.; Barros, S.B.M.; Mancini-Filho, J. Antioxidant activity of the microalga Spirulina maxima. Braz. J. Med. Biol. Res. 1998, 31, 1075-1079. [CrossRef]

58. Hosseini Tafreshi, A.; Shariati, M. Dunaliella biotechnology: Methods and applications. J. Appl. Microbiol. 2009, 107, 14-35. [CrossRef]

59. Xu, S.Y.; Huang, X.; Cheong, K.L. Recent advances in marine algae polysaccharides: Isolation, structure, and activities. Mar. Drugs 2017, 15, 388. [CrossRef]

60. Chakrabarti, S.; Guha, S.; Majumder, K. Food-derived bioactive peptides in human health: Challenges and opportunities. Nutrients 2018, 10, 1738. [CrossRef]

61. Barra, L.; Chandrasekaran, R.; Corato, F.; Brunet, C. The challenge of ecophysiological biodiversity for biotechnological applications of Marine Microalgae. Mar. Drugs 2014, 12, 1641-1675. [CrossRef]

62. Brunet, C.; Johnsen, G.; Lavaud, J.; Roy, S. Pigments and photoacclimation processes. In Phytoplankton Pigments, Characterization, Chemotaxonomy and Applications in Oceanography; Cambridge University Press: Cambridge, UK, 2011; p. 880. 
63. Volkman, J.K. Sterols in microorganisms. Appl. Microbiol. Biotechnol. 2003, 60, 495-506. [CrossRef]

64. Durmaz, Y. Vitamin E ( $\alpha$-tocopherol) production by the marine microalga Nannochloropsis oculata (Eustigmatophyceae) in nitrogen limitation. Aquaculture 2007, 272, 717-722. [CrossRef]

65. Gastineau, R.; Turcotte, F.; Pouvreau, J.-B.; Morançais, M.; Fleurence, J.; Windarto, E.; Prasetiya, F.; Arsad, S.; Jaouen, P.; Babin, M.; et al. Marennine, promising blue pigments from a widespread Haslea diatom species complex. Mar. Drugs 2014, 12, 3161-3189. [CrossRef]

66. Francavilla, M.; Trotta, P.; Luque, R. Phytosterols from Dunaliella tertiolecta and Dunaliella salina: A potentially novel industrial application. Bioresour. Technol. 2010, 101, 4144-4150. [CrossRef]

67. Copia, J.; Gaete, H.; Zúñiga, G.; Hidalgo, M.; Cabrera, E. Effect of ultraviolet B radiation on the production of polyphenols in the marine microalga Chlorella sp. Lat. Am. J. Aquat. Res. 2012, 40, 113-123. [CrossRef]

68. Goiris, K.; Van Colen, W.; Wilches, I.; León-Tamariz, W.; De Cooman, L.; Muylaert, K. Impact of nutrient stress on antioxidant production in three species of microalgae. Algal Res. 2015, 7, 51-57. [CrossRef]

69. Farahin, A.W.; Yusoff, F.M.; Nagao, N.; Basri, M.; Shariff, M. Phenolic content and antioxidant activity of Tetraselmis tetrathele (West) Butcher 1959 cultured in annular photobioreactor. J. Environ. Biol. 2016, 37, 631-639.

70. Morowvat, M.H.; Ghasemi, Y. Evaluation of antioxidant properties of some naturally isolated microalgae: Identification and characterization of the most efficient strain. Biocatal. Agric. Biotechnol. 2016, 8, 263-269. [CrossRef]

71. Pouvreau, J.B.; Morancais, M.; Taran, F.; Rosa, P.; Dufossé, L.; Guérard, F.; Pin, S.; Fleurence, J.; Pondaven, P. Antioxidant and free radical scavenging properties of marennine, a blue-green polyphenolic pigment from the diatom Haslea ostrearia (Gaillon/Bory) Simonsen responsible for the natural greening of cultured oysters. J. Agric. Food Chem 2008, 56, 6278-6286. [CrossRef]

72. Jerez-Martel, I.; García-Poza, S.; Rodríguez-Martel, G.; Rico, M.; Afonso-Olivares, C.; Gómez-Pinchetti, J.L. Phenolic profile and antioxidant activity of crude extracts from microalgae and cyanobacteria strains. J. Food Qual. 2017, 2017, 2924508. [CrossRef]

73. Borowitzka, M.A. Commercial-scale production of microalgae for bioproducts. In Blue Biotechnology: Production and Use of Marine Molecules; La Barre, S., Bates, S.S., Eds.; Wiley-VCH: Weinheim, Germany, 2018; Volume 1, pp. 33-65.

74. Cirulis, J.T.; Scott, J.A.; Ross, G.M. Management of oxidative stress by microalgae. Can. J. Physiol. Pharmacol. 2013, 9, 15-21. [CrossRef]

75. Haubrich, B.A. Microbial sterolomics as a chemical biology tool. Molecules 2018, 23, 2768. [CrossRef]

76. Stonik, V.A.; Stonik, I.A. Sterol and sphingoid glycoconjugates from microalgae. Mar. Drugs 2018, 16, 514. [CrossRef]

77. Smerilli, A.; Balzano, S.; Maselli, M.; Blasio, M.; Galasso, C.; Sansone, C.; Brunet, C. Antioxidant and photoprotection networking in the coastal diatom Skeletonema marinoi. Antioxidants 2019, 8. [CrossRef]

78. de la Coba, F.; Aguilera, J.; Figueroa, F.L.; De Gálvez, M.V.; Herrera, E. Antioxidant activity of mycosporine-like amino acids isolated from three red macroalgae and one marine lichen. J. Appl. Phycol. 2009, 21, 161-169. [CrossRef]

79. Dimier, C.; Saviello, G.; Tramontano, F.; Brunet, C. Comparative ecophysiology of the xanthophyll cycle in six marine phytoplanktonic species. Protist 2009, 160, 397-411. [CrossRef]

80. Sansone, C.; Galasso, C.; Orefice, I.; Nuzzo, G.; Luongo, E.; Cutignano, A.; Romano, G.; Brunet, C.; Fontana, A.; Esposito, F.; et al. The green microalga Tetraselmis suecica reduces oxidative stress and induces repairing mechanisms in human cells. Sci. Rep. 2017, 7, 41215. [CrossRef] [PubMed]

81. Williams, P.J.1.B.; Laurens, L.M.L. Microalgae as biodiesel \& biomass feedstocks: Review \& analysis of the biochemistry, energetics \& economics. Energy Environ. Sci. 2010, 3, 554.

(C) 2019 by the authors. Licensee MDPI, Basel, Switzerland. This article is an open access article distributed under the terms and conditions of the Creative Commons Attribution (CC BY) license (http://creativecommons.org/licenses/by/4.0/). 